\title{
PEMANFAATAN PEKTIN YANG DIISOLASI DARI KULIT DAN BUAH SALAK (Salacca Edulis Reinw) DALAM UJI IN VIVO PENURUNAN KADAR KOLESTEROL DAN GLUKOSA DARAH PADA TIKUS JANTAN GALUR WISTAR
}

Pradhani Dhaneswari, Crisdany Gusti Sula, Zahra Ulima, Putri Andriana

\author{
Jurusan Farmasi, Fakultas Matematika dan Ilmu Pengetahuan Alam, \\ Universitas Islam Indonesia
}

\section{RINGKASAN}

Pektin merupakan polimer yang terdapat dalam dinding sel tumbuhan dan dapat ditemukan dalam berbagai jenis tanaman pangan. Pektin pada tanaman banyak terdapat pada kulit dan daging buahnya. Pektin memiliki manfaat yang banyak, terutama di bidang kesehatan. Penelitian ini merupakan penelitian pendahuluan untuk mendapatkan pektin dari kulit dan daging buah salak pondoh (Salacca edulis Reinw.), yang keberadaannya berlimpah di Kabupaten Sleman, serta untuk mengetahui aktivitas penurunan kadar glukosa dan kolesterol dalam uji in vivo. Dilakukan 2 cara untuk mendapatkan pektin dari kulit dan daging buah salak, yaitu dengan soxhletasi dan perebusan. Untuk metode soxhletasi digunakan kondisi $\mathrm{pH} 2,5-3$, dengan suhu $90^{\circ} \mathrm{C}$. Sedangkan untuk metode perebusan, digunakan kondisi $\mathrm{pH} 1,5$ dengan suhu $80^{\circ} \mathrm{C}$. Tikus dibagi menjadi 3 kelompok untuk masing-masing uji penurunan kadar glukosa dan uji penurunan kadar kolesterol. Kelompok I kontrol normal hanya diberikan diet normal, kelompok II kontrol negatif hanya diberikan diet tinggi gula pada kelompok uji penurunan glukosa atau diet tinggi lemak pada kelompok uji penurunan kadar kolesterol, dan kelompok III perlakuan pektin 1,8g/kg BB beserta diet tinggi gula atau diet tinggi lemak. Kadar glukosa dan kolesterol dalam darah diukur pada akhir perlakuan. Kemudian data yang diperoleh dianalisis.

Kata kunci : pektin, salak pondoh, kadar glukosa, kadar kolesterol 


\section{PENDAHULUAN}

\section{A. Latar Belakang}

Salak pondoh (Salacca edulis Reinw.) merupakan komoditas unggulan dan keberadaannya sangat berlimpah di Kabupaten Sleman. Buah inimemilikikekhasan dan keistimewaan tersendiri, yaitu memiliki daging buah yang lebih besar dan tebal, serta memiliki rasa yang manis walaupun masih muda (Nazaruddindan Kritiawati, 1992). Daging buah salak pondoh dapat dikonsumsi langsung dan juga sering dibuat menjadi suatu olahan produk tertentu, misalnya keripik salak, bakpia salak, ataupun brownis salak. Diketahui bahwa daging buah salak pondoh mengandung serat pangan / dietary fibers total (insoluble dietary fiber dan pektin) paling tinggi kedua setelah salak "Gading Jawa"(Lestari, dkk, 2003). Sehingga dengan diketahuinya hal tersebut, tingkat konsumsi daging buah salak menjadi lebih tinggi. Akan tetapi, pemanfaatan kulit dari buah salak pondoh sebagai bahan pangan belum pernah dilakukan dan peneliti belum menemukan penelitian ilmiah yang membuktikan potensi serta senyawa aktif yang ada pada kulit dari buah salak. Pemanfaatan kulit dari buah salak pondoh yang telah dilakukan saat ini hanyalah menghasilkan berupa kerajinan gerabah ataupun tas.

Pektin merupakan suatu senyawa polisakarida kompleks yang cenderung banyak terdapat dalam dinding sel tumbuhan dan dapat ditemukan dalam berbagai jenis tanaman pangan. Pektin memiliki banyak manfaat, terutama dibidang farmasi, dimana pektin banyak digunakan untuk emulsifier bagi peparat cair dan sirup, sebagai antidotum, sebagai adsorben pada pengobatan diare (Winarno, 1986), dan telah diketahui bahwa dengan mengkonsumsi pektin, akan mampu mengurangi kadar kolesterol dalam darah, dimana dengan mengkonsumsi sedikitnya 6 gram pektin per hari akan mampu mengurangi kadar kolesterol dalam darah hingga $13 \%$ dalam jangka waktu 2 minggu (Srivastava and Rishabha, 2011). Biasanya penurunan kadar glukosa yang di serap tubuh, memiliki hubungan yang erat dengan penurunan kolesterol dalam darah. Oleh karena itulah dilakukan penelitian ini dengan harapan agar menjadi langkah awal dalam pengembangan pemanfaatan kulit dan daging buah salak, tidak hanya sebagai bahan pangan, yaitu sebagai sumber pektin baru yang murah, tetapi juga dapat digunakan dalam bidang kesehatan terutama dalam membantu penurunan 
kadar kolesterol pada penderita hiperkolesterolemia (anti hiperkolesterolemia) dan penurunan kadarglukosa darah pada penderita hiperglikemia (anti hiperglikemia). Sehingga, dapat dimanfaatkan oleh masyarakat luas, terutama masyarakat Kabupaten Sleman, mengingat melimpahnya jumlah salak pondoh di daerah Sleman, Yogyakarta.

\section{B. Perumusan Masalah}

Berdasarkan latar belakang dan uraian tersebut diatas, maka dapat dirumuskan suatu permasalahan sebagai berikut:

1. Apakah kulit dan daging buah salak pondoh dapat dijadikan sebagai sumber pektin yang baru yang lebih murah?

2. Apakah bisa didapatkan metode yang tepat dalam isolasi pektin dari kulit dan daging buah salak pondoh?

3. Apakah pektin yang diisolasi dari kulit dan daging buah salak pondoh memiliki aktivitas penurunan kadar kolesterol dan glukosa darah dalam pengujian secara in vivo?

4. Bagaimanakah pengaruh pemberian pektin terhadap kadar kolesterol dan glukosa darah pada tikus galur wistar?

\section{Tujuan Program}

Berdasarkan rincian masalah di atas, maka penelitian ini dilakukan dengan tujuan sebagai berikut:

1. Membuktikan bahwa kulit dan daging buah salak pondoh dapat dijadikan sebagai sumber pektin yang baru dan lebih murah.

2. Mendapatkan metode yang tepat dalam isolasi pektin dari kulitdan daging buah salak pondoh.

3. Membuktikan bahwa pektin yang diisolasi dari kulit dan daging buah salak pondoh memiliki aktifitas dalam menurunkan kadar kolesterol dan glukosa darah.

4. Menganalisis pengaruh pemberian pektin terhadap kadar kolesterol dan glukosa darah pada tikus jantan galur wistar.

\section{Luaran Yang Diharapkan}

Luaran yang diharapkan dengan adanya PKM-P yang akan dilaksanakan ini adalah:

1. Didapatkan sumber pektin yang baru dan lebih murah, yaitu dari kulit dan daging buah salak pondoh.

2. Didapatkan metode yang tepat dalam isolasi pektin dari kulitdan daging buah salak pondoh.

3. Dapat meningkatkan pemanfaatan kulit dan daging buah salak pondoh dibidang kesehatan.

4. Membuktikan penggunaan atas dasar empiris ke dalam penelitian secara in vivo. 


\section{E. Kegunaan Program}

Dengan dilakukannya penelitian ini memiliki banyak kegunaan yaitu:

1. Memberikan wawasan lebih terkait dengan fungsi pektin dalam kulit dan daging buah salak pondoh yang ada di Kabupaten Sleman, Yogyakarta.

2. Meningkatkan kesejahteraan petani salak, dengan permintaan lebih dari konsumen akan manfaat penting yang terkandung dalam kulit dan daging buah salak.

3. Membuktikan kebenaran empiris terhadap fungsi kulit dan daging buah salak dalam menurunkan kadar kolesterol dan glukosa darah.

\section{F. TINJAUAN PUSTAKA}

\section{Salak Pondoh}

Salak pondoh termasuk dalam spesies Salacca edulis Reinw dan masuk dalam keluarga Salacca (Anarsis, 1996). Salak pondoh memiliki ciri-ciri daunnya pecah berbentuk menyirip, permukaan atas daun berwarna hijau tua mengkilap dan permukaan bawahnya berwarna keputih-putihan berlapis lilin. Jenis salak ini dibedakan atas dua subspecies atau varietas, yaitu Salacca zalacca varietas zalacca dan Salacca zalacca varietas amboinensis. Salacca zalacca varietas zalacca disebut salak jawa. Salak jawa umumnya berumah dua, sehingga pembuahannya membutuhkan bantuan penyerbukan. Jenis salak inilah yang memiliki banyak varietas yang tersebar diberbagai daerah jawa, Madura, dan Sumatera Selatan. Kandungan buah salak pondoh dalam tiap 100 gram menurut direktorat gizi departemen kesehatan

(1981) disajikan pada tabel 1 .

Tabel 1. Kandungan gizi buah salak pondoh

\begin{tabular}{|c|c|}
\hline Kandungan Gizi & Jumlah \\
\hline Kalori $(\mathrm{g})$ & 77 \\
\hline Protein $(\mathrm{g})$ & 0,40 \\
\hline Karbohidrat $(\mathrm{g})$ & 20,90 \\
\hline Kalsium $(\mathrm{g})$ & 28 \\
\hline Fosfor $(\mathrm{g})$ & 18 \\
\hline Zat besi (g) & 4,2 \\
\hline Vitamin B (g) & 0,04 \\
\hline Air (g) & 78 \\
\hline Bagian yang dikonsumsi (\%) & 50 \\
\hline
\end{tabular}

(Direktorat Gizi Departemen Kesehatan Republik Indonesia, 1981)

Kandungan zat kimia yang terdapat pada daging buah salak akan mengalami perubahan dengan semakin menuanya buah. Pada salak pondoh, perubahan kandungan zat gula tertinggi pada umur 5 bulan, yaitu 23,3\% sedangkan pada umur 3,5 bulan kandungan gulanya $15,35 \%$ (Sabari, 1983). Pemecahan pektin dan hemiselulosa di lamella tengah akan melemahkan dinding sel dan mengurangi kekuatan 
mengikat kohesif antara sel-sel. Hal ini sangat terkait dengan pengurangan ketegasan buah. Saat pematangan berlangsung, insoluble pectin (ISP) dalam dinding sel diubah menjadi water soluble pectin (WSP) oleh aksi hidrolisis dinding sel, yang ditunjukkan oleh penurunan kandungan ISP dan peningkatan WSP (Lestari, dkk, 2013).

\section{Pektin}

Pektin pada sel tumbuhan merupakan penyusun lamella tengah, yaitu lapisan penyusun awal dinding sel. Pada sel-sel tertentu seperti buah atau kulit buah, cenderung mempunyai kandungan pektin yang sangat banyak. Berdasarkan berbagai studi, diketahui bahwa strutur pektin sulit untuk ditentukan karena komposisi sub-unitnya dapat berubah ketika proses isolasi (Srivastava and Rishabha, 2011). Komposisi utama pektin adalah unit-unit asam D-Galakturonik (Ga1A) yang membentuk ikatan $\alpha-(1,4)$ glikosidik. Ion $\mathrm{Mg}^{+}$atau $\mathrm{Ca}^{+}$ inilah yang menyebabkan rasa lengket pada kulit, serta pektin tidak larut dalam air dan dapat membentuk gel, karena ikatan tersebut berstruktur amorphous (Srivastava and Rishabha, 2011).

Studi yang telah dilakukan oleh Frank Mattes, membuktikan bahwa pektin dapat menurunkan kadar kolesterol dalam darah. Pektin juga telah diketahui sebagai serat soluble yang paling efektif sebagai penurun kadar kolesterol apabila dibandingkan dengan fisilium, oat, dan guargum (Mattes, 2005). Pektin bersifat resisten terhadap sistem pencernaan manusia (amilase), akan tetapi hampir terdegradasi sempurna oleh aerobacillus, lactobacillus, micrococcus, dan enterococcus bacteria pada kolon. Flora bakteri normal dalam usus manusia tersebut dapat menguraikannya dan membebaskan produk tersebut ke dalam lumen usus. Bakteri tersebut memproduksi enzim pektolitik yang mendegradasi pektin menjadi asam lemak rantai pendek (asam asetat, asam butirat, asam propionat), $\mathrm{CO}_{2}, \mathrm{H}_{2} \mathrm{O}, \mathrm{H}_{2}$, dan metana, kemudian produk tersebut akan diserap tubuh. Hal inilah yang menyebabkan pektin bersifat laksatif dan menstimulasi pertumbuhan bakteri pada kolon (Mattes, 2005, Sharma, et al, 2006).

Mekanisme kerja pektin adalah pektin mampu mengikat kolesterol yang terdapat pada sistem pencernaan, sehingga mencegahnya untuk diserap menujualiran darah. Semakin tinggi visikositas pektin maka semakin efektif dalam menyerap kolesterol. Pektin dengan visikositas tinggi 
akan menurunkan kadar kolesterol dengan cara meningkatkan ekskresi asam empedu feses dan sterol netral. Pektin yang memiliki visikositas tinggi tersebut akan berperan dalam membentuk misela dan asam empedu dengan laju difusi rendah melalui bolus untuk mengikat kolesterol (Sharma et al, 2006, Marks, 1996). Sedangkan mekanismenya terhadap kadar glukosa plasma adalah senyawa ini mengganggu pencernaan intralumen bagi pati dan sukrosa, sehingga menunda absorbsi karbohidrat. Selain itu pektin akan membentuk gel dan menahan air sehingga dapat memperlambat pengosongan lambung (Marks, 1996).

\section{Hiperkolesterolemia Dan Hiperglikemia \\ Hiperkolesterolemia adalah} kondisi saat konsentrasi kolesterol di dalam darah melebihi batas normal, dengan kadar kolesterol total plasma $\geq 200 \mathrm{mg} / \mathrm{dl}$. Peningkatan kolesterol dalam darah disebabakan kelainan pada tingkat lipoprotein. Hiperglikemia menurut World Health Organization (WHO) adalah kadar glukosa darah (KGD) $\geq 126 \mathrm{mg} / \mathrm{dL}$ (7,0 mmol/L), dimana KGD antara 100 dan $126 \mathrm{mg} / \mathrm{dL}$ (6,1 sampai $7,0 \mathrm{mmol} / \mathrm{L}$ ) dikatakan suatu keadaan toleransi abnormal glukosa.

\section{G. METODE PENDEKATAN}

\section{Bahan dan Alat}

\section{Bahan}

\section{Pembuatan Pektin}

Bahan yang digunakan dalam penelitian ini adalah kulit dan daging buah salak pondoh (Salacca edulis Reinw.) yang diperoleh dari perkebunan salak di Desa Candibinangun, Kecamatan Pakem, Kabupaten Sleman, Yogyakarta, aquadest, $\mathrm{HCl} 5 \%$, kain saring, etanol $96 \%$, dan $\mathrm{AgNO}_{3}$.

\section{Subjek uji}

Subjek penelitian adalah tikus putih jantan galur wistar sebanyak 36 ekor yang berumur 1,5-2 bulan dengan berat badan \pm 180 gram, dalam keadaan sehat dan aktif yang diperoleh dari peternak khusus hewan uji dengan sertifikat sehat. Tikus dikandangkan terpisah berdasarkan kelompok.

\section{Uji penurunan kadar glukosa dan kolesterol}

Bahan yang digunakan dalam uji penurunan kadar glukosa dan kolesterol dalam darah adalah pakan standar BR II, tepung, gula, lemak sapi, minyak hewani, kuning telur, dan aquadest.

Penetapan kadar glukosa dan kolesterol dalam darah

Bahan yang digunakan untuk menetapkan kadar glukosa dan kolesterol adalah reagen GODPAP, reagen Fluitest ${ }^{\circledR} \mathrm{CHOL}$, dan EDTA sebagi anti koagulan. 


\section{Alat}

Alat utama yang digunakan dalam penelitian ini adalah lemari pengering, spektrofotometer UVVis, oven, ayakan nomor mesh 60 , miller, blender, pemanas listrik, rotary evaporator, magnetic stirrer, timbangan analitik, timbangan tikus, waterbath, spindown, inkubator, $\mathrm{pH}$ meter, kandang tikus, seperangkat alat gelas, termometer, spuit oral tikus 1-5 $\mathrm{mL}$, mikropipet, ependorf $1,5 \mathrm{~mL}$, pipa kapiler dengan heparin, Blue tip, yellow tip.

\section{Sistematika Kerja Penelitian}

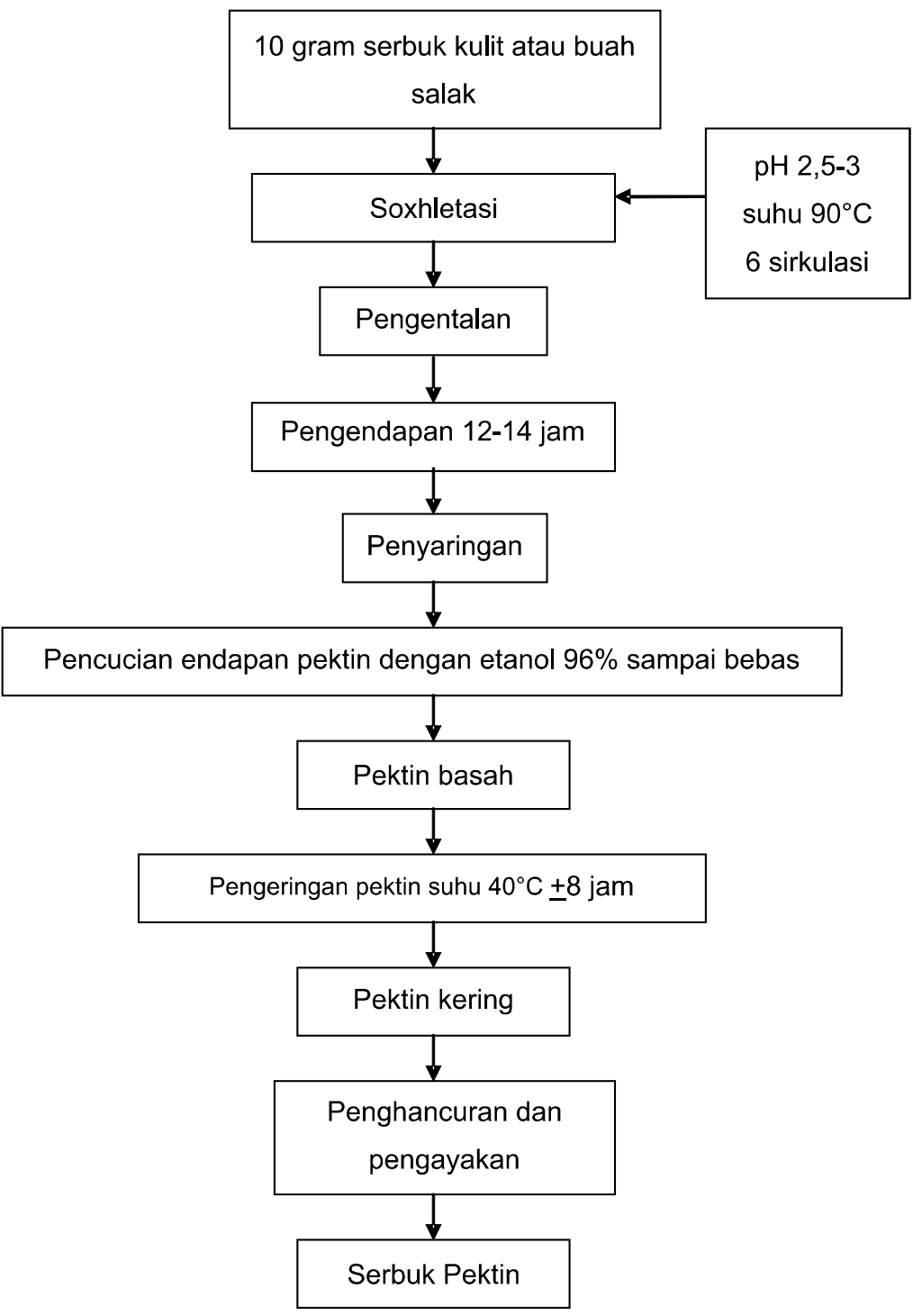

Gambar 1. Skematika Ekstraksi pektin dengan metode soxhletasi 
KHAZANAH, Vol. 7 No.2 Januari 2015

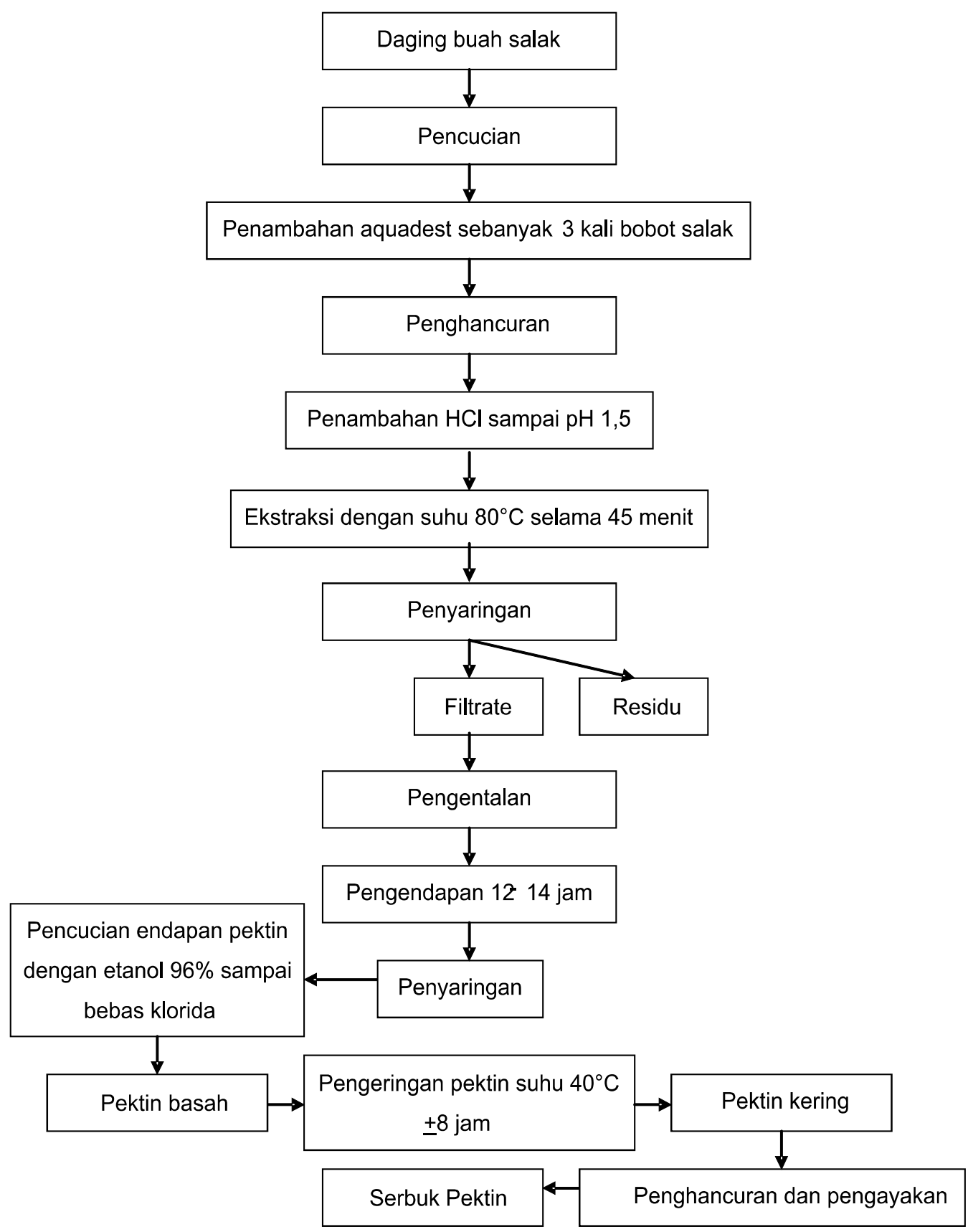

Gambar 2. Skematika Ekstraksi pektin dengan metode perebusan 


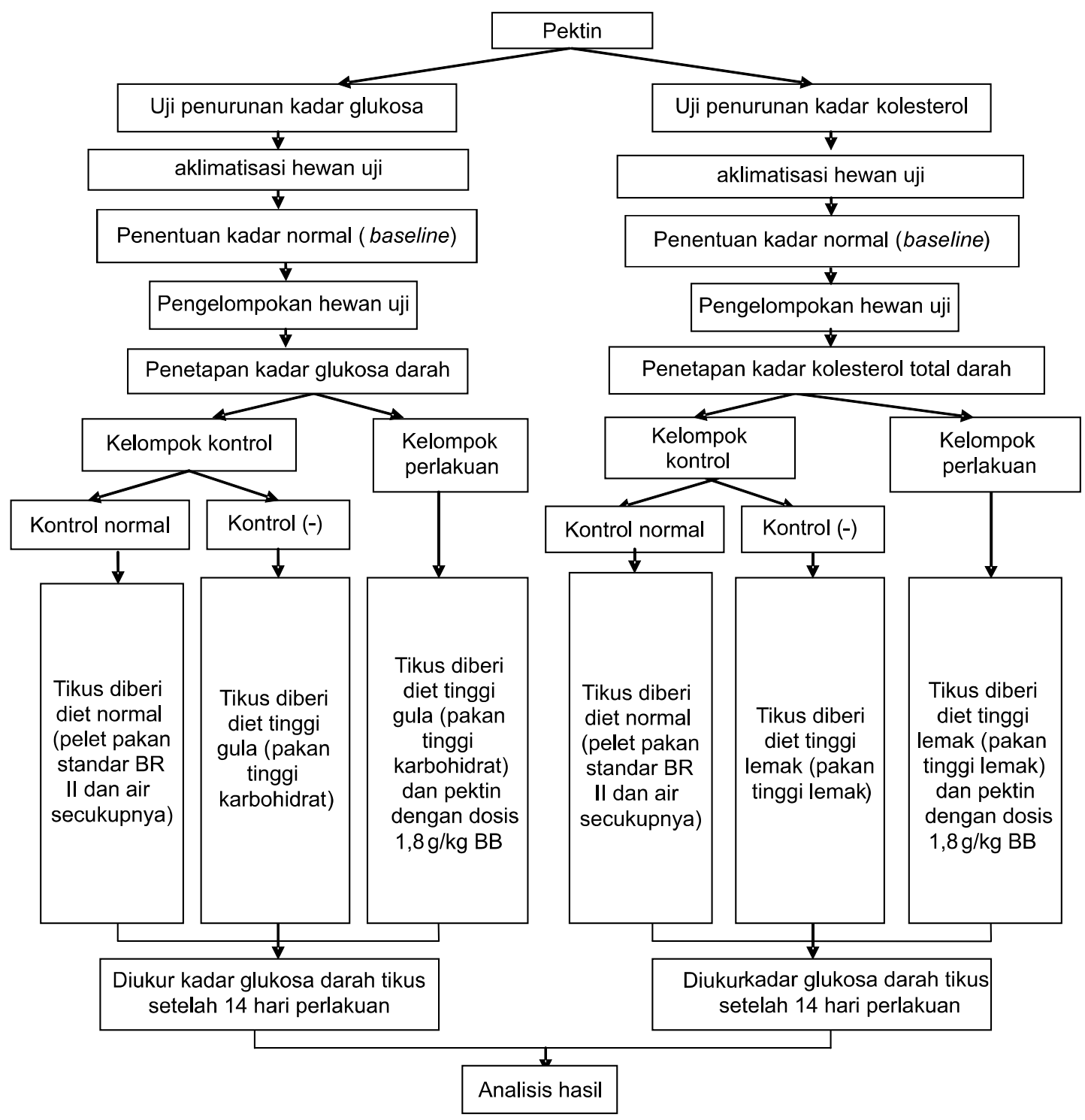

Gambar 3. Skematika Uji aktitas in vivo

Cara Penelitian

1. Pembuatan pektin dengan metode`soxhletasi

Persiapan Bahan

Buah dicuci dari tanah dan kotoran lainnya. Kulit dan daging buah dipisahkan, kemudian daging buah dipotong tipis-tipis. Masingmasing (kulit dan daging buah) dikeringkan dalamlemaripengering dengan suhu berkisar antara 30 $45^{\circ} \mathrm{C}$. kemudian simplisia kering diserbuk menggunakan miller. 


\section{Ekstraksi pektin}

10 gram serbuk diekstraksi dengan metode soxhletasi menggunakan pelarut aquadest yang telah diasamkan menggunakan $\mathrm{HCl} 5 \%$ sampai $\mathrm{pH}$ mencapai 2,53 dengan suhu $90^{\circ} \mathrm{C}$. Kemudian, pelarut diuapkan hingga sekitar setengah dari volume awal.

\section{Pengendapan (Isolasi)}

Didinginkan filtrat kental pada suhu kamar $\left(25^{\circ} \mathrm{C}\right)$. Kemudian diendapkan dengan etanol $96 \%$ (filtrat : etanol 1:1) selama 10 menit dan dilakukan sentrifugasiselama 15 menit pada 8000 rpm. Disaring endapan pektin menggunakan kertas saring.

\section{Pengeringan}

Dipisahkan supernatant dari presipitat dan mengyapkan pelarut yang tersisa dengan menggunakan cawan pada suhu rendah.

\section{Pembuatan pektin dengan metode perebusan}

\section{Persiapan bahan}

Buah dicuci dari tanah dan kotoran lainnya. Kulit dan daging buah dipisahkan, kemudian daging buah dicuci dengan air dingin untuk mengurangi senyawa gula yang terkandung didalamnya dan diganti beberapa kali agar pencucian dapat berhasil baik.

\section{Ekstraksi pektin}

Diblender salak yang telah ditambahkan air dengan perbandingan salak air (1:3). Ditambah $\mathrm{HCl} 5 \%$ hingga $\mathrm{pH}$ menjadi 1,5 . Kemudian dipanaskan pada suhu $80^{\circ} \mathrm{C}$ selama 45 menit sambil diaduk. Disaring dan diperas menggunakan kain saring yang tebal. Lalu dikentalkan menggunakan suhu $80^{\circ} \mathrm{C}$ hingga bobotnya setengah dari bobot awal

\section{Pengendapan (Isolasi)}

Didinginkan filtrat kental pada suhu kamar $\left(25^{\circ} \mathrm{C}\right)$. Kemudian diendapkan dengan etanol $96 \%$ yang telah diasamkan dengan $2 \mathrm{~mL}$ $\mathrm{HCl}$ tiap $1 \mathrm{~L}$ etanol (filtrat : etanol 1:1) selama 12-14 jam. Disaring endapan pektin menggunakan kain saring.

\section{Pencucian}

Dicuci endapan pektin dengan etanol 96\%. Kemudian disaring menggunakan kain saring. Cairan bekas cucian pektin ditetesi dengan perak nitrat $\left(\mathrm{AgNO}_{3}\right)$ untuk mengetahui apakah masih terdapat klorida atau tidak (endapan putih / $\mathrm{AgCl})$.

\section{Pengeringan}

Dikeringkan pektin basah dalam oven pada suhu $40^{\circ} \mathrm{C}$ selama 8 jam. Lalu diblender pektin kering dan diayak menggunakan ayakan mesh 60 .

3. Komposisi Pakan Diet Tinggi karbohidrat dan Lemak 
Pemanfaatan Pektin Yang Diisolasi...........Pradhani, Crisdany, Zahra, Putri.

Tabel 2. Komposisi Pakan Tikus

\begin{tabular}{|c|c|c|c|}
\hline Bahan & $\begin{array}{c}\text { Diet Normal } \\
(\mathrm{g})\end{array}$ & $\begin{array}{c}\text { Diet Tinggi } \\
\text { Karbohidrat } \\
(\mathrm{g})\end{array}$ & $\begin{array}{c}\text { Diet Tinggi Lemak } \\
(\mathrm{g})\end{array}$ \\
\hline $\begin{array}{c}\text { Comfeed Pars (BR } \\
\text { II) }\end{array}$ & 200 & 200 & 200 \\
\hline Terigu & 100 & 100 & 100 \\
\hline Gula & - & 80 & - \\
\hline Kolesterol & - & - & 8 \\
\hline Kuning Telur & - & - & 32 \\
\hline Lemak Sapi & - & - & 71,2 \\
\hline Air (mL) & 71,2 & secukupnya & 30 \\
\hline Berat Pakan (g/hari) & 30 & 30 & \\
\hline
\end{tabular}

(Tsalissavrina, I., dkk, 2006).

\section{Penetapan Dosis Pektin}

Penentuan dosis pektin berdasarkan konsumsi harian pektin oleh manusia yaitu 6 sampai 30 gram per harinya. Berdasarkan penelitian yang telah dilakukan oleh Hari di sarankan untuk meningkatkan dosis diatas 15 gram dosis manusia, sehingga pada penelitian ini digunakan dosis pektin 20 gram pada penggunaan manusia.

Dosis konversi

$=0,018 \times 20 \mathrm{~g} / 70 \mathrm{~kg} \mathrm{BB}$

$=0,36 \mathrm{~g} / 200 \mathrm{~g}$ BB tikus

$=1,8 \mathrm{~g} / \mathrm{kg} \mathrm{BB}$

Volume pemejanan

$=1 \mathrm{ml} / 200 \mathrm{~g} \mathrm{BB}$ tikus Larutan stok

$=$ dosis : volume pemejanan

$=(0,36 \mathrm{~g} / 200 \mathrm{~g} \mathrm{BB}):(1 \mathrm{ml} / 200 \mathrm{~g} \mathrm{BB})$

$=0,36 \mathrm{~g} / 1 \mathrm{ml}$

$=4,32 \mathrm{~g} / 12 \mathrm{ml}$

5. Perlakuan hewan uji.

Orientasi lama waktu pemberian diet

Orientasi lama pemberian diet dilakukan selama 8 sampai 10 minggu. Pemeriksaan terhadap kadar kolesterol dilakukan pada minggu ke-2, 4, 8, dan 10 (Mawarti, H., dan Ratnawati, R., 2012, Tsalissavrina, I., dkk, 2006). Sedangkan pemeriksaan terhadap kadar glukosa dilakukan pada akhir diet setelah dipuasakan 8-10 jam. Waktu pemberian diet dilakukan sampai didapatkan kadar hiperkolesterolemia dan hiperglikemia.

\section{Uji penurunan kadar glukosa}

Hewan uji menggunakan tikus putih jantan galur wistar, terdiri dari 3 kelompok, tiap kelompok terdiri dari 6 ekor tikus.

Kelompok kontrol normal : diet normal (pakan standar BR II atau pelet dan air secukupnya).

Kelompok kontrol negatif : diet tinggi gula (pakan tinggi karbohidrat).

Kelompok perlakuan : diet tinggi gula (pakan tinggi karbohidrat) dan pektin dosis $1,8 \mathrm{~g} / \mathrm{kg} \mathrm{BB}$. 
Perlakuan dilakukan selama 14 hari. Pengambilan darah dilakukan pada hari terakhir setelah dipuasakan 8-10 jam.

\section{Uji penurunan kadar kolesterol}

Hewan uji menggunakan tikus putih jantan galur wistar, terdiri dari 3 kelompok, tiap kelompok terdiri dari 6 ekor tikus.

Kelompok kontrol normal : diet normal (pakan standar BR II atau pelet dan air secukupnya).

Kelompok kontrol negatif : diet tinggi lemak (pakan tinggi lemak).

Kelompok perlakuan :diet tinggi lemak (pakan tinggi lemak) dan pektin dengan dosis $1,8 \mathrm{~g} / \mathrm{kg} \mathrm{BB}$.

Perlakuan dilakukan selama 14 hari. Pengambilan darah dilakukan pada hari terakhir.

\section{Penetapan kadar glukosa}

Darah hewan uji diambil $3 \mathrm{ml}$ dimasukkan kedalam tube vialyang telah diberi antikoagulan (EDTA) perbandingan 1:1. Kemudian diambil plasma darahnya, ditambahkan reagen uji pada sampel dan dimasukkan inkubator 10 menit pada suhu $37^{\circ} \mathrm{C}$. Diukur absorbansi standar (A-std) dan sampel (A-spl) terhadap blanko reagen (RB) dengan panjang gelombang $500 \mathrm{~nm}$. Perhitungan kadar glukosa :

Kadar glukosa $(\mathrm{mg} / \mathrm{dL})=\mathrm{A}-\mathrm{spl} /$ A-std $\mathrm{x}$ konsentrasi standar

\section{Penetapan kadar kolesterol}

Darah hewan uji diambil $3 \mathrm{ml}$, kemudian disentrifugasi dengan kecepatan 3000 rpm selama 5 menit, serum ditampung dalam tabung mikro. Larutan standar kolesterol maupun sampel (masing-masing $10 \mu \mathrm{l}$ ) ditambah pereaksi monotest kolesterol sebanyak $1000 \mu$ l. Sebagai blanko adalah pereaksi monotest kolesterol. Masing-masing larutan diaduk, diinkubasi selama 10 menit pada suhu $37^{\circ} \mathrm{C}$. Diukur absorbansi standar (A-std) dan sampel (A-spl) terhadap blanko reagen (RB) dengan panjang gelombang $500 \mathrm{~nm}$. Perhitungan kadar glukosa :

Kadar glukosa $(\mathrm{mg} / \mathrm{dL})=\mathrm{A}-\mathrm{spl} /$ A-std $\mathrm{x}$ konsentrasi standar

\section{H. PELAKSANAAN PROGRAM}

\section{Pembuatan pektin dengan metode soxhletasi}

Soxhletasi dilakukan sampai 6 kali siklus, dengan setiap siklus tercapai selama \pm 1 jam. Pelarut yang digunakan adalah aquadest yang diasamkan dengan $\mathrm{HCl} 5 \%$ sampai kisaran $\mathrm{pH} 2,5$ sampai 3 pada suhu $90 \square \mathrm{C}$. Larutan pengendap digunakan 2 macam, yaitu etanol $96 \%$ yang diasamkan dengan $\mathrm{HCl}$ pekat dan etanol $96 \%$ tanpa $\mathrm{HCl}$. Kemudian dilakukan sentrifugasi selama 15 menit dengan kecepatan 8000 rpm. Disaring endapan pektin 
menggunakan kertas saring. Pelarut yang tersisa diuapkan dengan menggunakan cawan pada suhu rendah. Selanjutnya dikeringkan dengan oven pada suhu rendah (45-50 $\square$ C). Karena isolasi pektin dari kulit dan daging buah salak baru pertama kali dilakukan, banyak kendala yang ditemui dan perlu dilakukan optimasi dengan mengacu pada beberapa studi pustaka untuk menemukan metode yang tepat, sehingga diperlukan waktu yang cukup lama dari tahap preparasi simplisia sampai didapatkan pektin kering. Tahap ini dilakukan di Laboratorium Biologi Farmasi Universitas Islam Indonesia, dengan waktu pelaksanaannya dilakukan dari tanggal 25 Maret sampai 27 Mei 2014.

\section{Pembuatan pektin dengan metode perebusan}

Pada tahap ini bagian yang digunakan adalah daging buah yang masih segar, tetapi untuk bagian kulitnya, digunakan dalam bentuk serbuk kering. Pada tahap ini dilakukan optimasi jumlah pelarut, suhu perebusan dan lama pengendapan. Perbandingan daging buah dengan aquadest didapatkan 1:3, sedangkan perbandingan serbuk kulit salak dengan aquadest didapatkan 1:6. Tahap perebusan dilakukan dengan pelarut aquadest dan dipanaskan pada 2 rentang suhu yaitu $80 \square \mathrm{C}$ dan $95 \square \mathrm{C}$. Proses perebusan dilakukan dalam keadaan asam dengan $\mathrm{pH} 1,5$ dalam waktu selama 45 menit. Proses pengendapan dilakukan pada 2 waktu, yaitu diendapkan semalam (12-14 jam) dan selama 30 menit. Pektin dikeringkan pada suhu rendah (40 $\square-50 \square$ C) selama 8 jam. Tahap ini dilakukan di Laboratorium Biologi Farmasi Universitas Islam Indonesia, dengan waktu pelaksanaannya dilakukan dari tanggal 28 Mei sampai 20 Juni 2014.

3. Penetapan Baseline kelompok glukosa dan kelompok kolesterol

Penetapan kadar glukosa dan kolesterol pada awal setelah adaptasi selama seminggu sebelum induksi diet maupun perlakuan, dilakukan untuk mengetahui kadar normal tiap tikus, sehingga dapat dilakukan pengelompokkan dengan persebaran variasi kadar glukosa maupun kolesterol secara merata untuk menghindarkan kejadian bias. Darah diambil dari plexus retroorbitalis menggunakan pipa kapiler. Pada penetapan kadar glukosa digunakan sampel serum (tanpa penambahan antikoagulan) sedangkan pada penetapan kadar kolesterol digunakan sampel plasma (ditambahkan heparin). Untuk mendapatkan sampel serum 
maupun plasma, darah yang didapatkan disentrifuge selama 15 menit dengan kecepatan $3500 \mathrm{rpm}$. Serum dan plasma yang diperoleh langsung dianalisis kadar glukosa maupun kolesterol totalnya di LPPT. Tahap aklimatisasi sampai penentuan kadar baseline dilakukan di Laboratorium Pengujian hewan/Pra Klinis Universitas Islam Indonesia, dengan waktu pelaksanaannya dilakukan dari tanggal 21 Juni sampai 29 juni 2014.

\section{Induksi hiperkolesterol dan} hiperglikemia

Pada tahap ini, tikus diberikan diet tinggi karbohidrat atau diet tinggi lemak sesuai dengan kelompok masing-masing, sehingga didapatkan kadar hiperglikemia untuk kelompok penurunan kadar glukosa darah dan kadar hiperkolesterolemia untuk kelompok penurunan kadar kolesterol total darah. Berdasarkan literatur, induksi hiperkolesterolemia maupun hiperglikemia idealnya dapat tercapai antara 8 sampai 10 minggu. Tetapi induksi hanya dilakukan sampai minggu ke-3 pemberian diet. Tahap Induksi hiperkolesterol dan hiperglikemia dilakukan di Laboratorium Pengujian hewan I Pra Klinis Universitas Islam Indonesia, dengan waktu pelaksanaannya dilakukan dari tanggal 30 juni sampai 21 juli 2014.

\section{Uji aktivitas secara in vivo}

Pada tahap ini belum sempat dilakukan peneliti karena keterbatasan waktu maupun dana.

\section{Jadwal pelaksanaan}

\begin{tabular}{|c|c|c|c|c|c|c|c|c|c|c|c|c|c|c|c|c|c|c|c|c|c|}
\hline \multirow{3}{*}{ Kegiatan } & \multicolumn{21}{|c|}{ Bulan ke- } \\
\hline & \multicolumn{4}{|c|}{1} & \multicolumn{4}{|c|}{2} & \multicolumn{4}{|c|}{3} & \multicolumn{5}{|c|}{4} & \multicolumn{4}{|c|}{5} \\
\hline & 1 & 2 & 3 & 4 & \begin{tabular}{l|l}
1 \\
\end{tabular} & 2 & 3 & 4 & 1 & 2 & 3 & 4 & 1 & & 2 & 3 & 4 & 1 & 2 & 3 & 4 \\
\hline $\begin{array}{l}\text { Preparasi } \\
\text { simplisia }\end{array}$ & & & & & & & & & & & & & & & & & & & & & \\
\hline $\begin{array}{c}\text { Ekstraksi pekti } \\
\text { dengan } \\
\text { soxhletasi }\end{array}$ & & & & & & & & & & & & & & & & & & & & & \\
\hline $\begin{array}{c}\text { Ekstraksi pekti } \\
\text { dengan } \\
\text { perebusan }\end{array}$ & & & & & & & & & & & & & & & & & & & & & \\
\hline $\begin{array}{c}\text { Penetapan } \\
\text { Baseline } \\
\text { kelompok } \\
\text { glukosa dan } \\
\text { kelompok } \\
\text { kolesterol }\end{array}$ & & & & & & & & & & & & & & & & & & & & & \\
\hline $\begin{array}{c}\text { Induksi } \\
\text { hiperkolestero } \\
\text { dan } \\
\text { hiperglikemia }\end{array}$ & & & & & & & & & & & & & & & & & & & & & \\
\hline $\begin{array}{l}\text { Uji aktivitas } \\
\text { secara in vivo }\end{array}$ & & & & & & & & & & & & & & & & & & & & & \\
\hline $\begin{array}{l}\text { Penyusunan } \\
\text { laporan akhir }\end{array}$ & & & & & & & & & & & & & & & & & & & & & \\
\hline
\end{tabular}




\section{HASIL DAN PEMBAHASAN}

Pemanfaatan pektin yang diisolasi dari kulit dan daging buah salak sebagai anti hiperglikemik dan anti hiperkolesterolemia telah sampai pada tahap induksi hiperkolesterolemia dan hiperglikemia. Dimana proses ekstraksi yang dilakukan adalah dengan membandingkan dua metode yang berbeda, yaitu soxhletasi dan pemanasan. Pada metode sokhletasi, digunakan 10 gram serbuk simplisia daging buah salak. Setelah beberapa kali dilakukan optimasi berdasarkan studi literature, didapatkan serbuk pektin sejumlah $0,3 \mathrm{mg}$. Pada metode perebusan, untuk 400 gram daging buah salak segar, didapatkan serbuk pektin sejumlah 4,9 gram, sedangkan untuk 60,08 gram kulit buah salak, didapatkan serbuk pektin sejumlah 4,03 gram.

\section{Evaluasi Keberhasilan Hasil}

\section{Penyiapan simplisia}

Simplisia dibuat dari kulit dan daging buah salak yang dikeringkan di dalam lemari pengering. Pada saat penelitian kulit buah salak lebih cepat kering dibandingkan dengan daging buah. Untuk kulit buah salak diperlukan waktu 3 hari sedangkan untuk daging buah diperlukan waktu 21 hari. Berdasarkan beberapa studi literatur, daging buah salak lebih lama kering dikarenakan kadar air yang lebih banyak (80\%) dibandingkan kadar air pada kulit salak. Simplisia daging salak kering yang didapat bersifat higroskopis karena saat preparasi tidak dilakukan proses pencucian. Proses pencucian mengguanakan air dingin bertujuan untuk mengurangi kadar gula dalam daging buah, dimana gula bersifat menyerap air ataupun udara lembab (higroskopis), sehingga dapat mempengaruhi sifat simplisia kering menjadi higroskopis.

\section{Isolasi pektin dengan metode sokhletasi}

Pada tahap soxhletasi, pelarut yang digunakan adalah aquadest yang diasamkan dengan $\mathrm{HCl} 5 \%$ sampai kisaran $\mathrm{pH}$ 2,5 sampai 3 pada suhu $90 \square \mathrm{C}$. Penentuan $\mathrm{pH}$ ini berdasarkan beberapa studi pustaka yang menyatakan rendemen paling besar berada pada $\mathrm{pH}$ 2,5-3. Alasan penggunaan suhu sampai $90 \square \mathrm{C}$, karena pelarut yang digunakan adalah aquadest yang memiliki titik didih yang cukup tinggi, yaitu $100 \square$ C. Titik didih tersebut akan mempengaruhi waktu yang diperlukan untuk mencapai tiap satu siklus sokhletasi. Semakin tinggi titik didih, maka waktu yang diperlukan agar tercapai tiap satu siklus akan semakin besar. Oleh karena itu, untuk mengurangi waktu 
sokhletasi, maka dapat dilakukan peningkatan suhu, selama senyawa yang ingin diisolasi masih bertahan dan tidak rusak pada suhu pemanasan tersebut. Pada tahap ini, sokhletasi dilakukan sampai 6 kali siklus, dengan setiap siklus tercapai selama \pm 1 jam. Larutan pengendap yang digunakan dibedakan menjadi 2 macam, yaitu etanol $96 \%$ yang diasamkan dengan $\mathrm{HCl}$ pekat dan etanol $96 \%$ tanpa $\mathrm{HCl}$. Perlakuan ini dilakukan untuk mengetahui hasil mana yang memberikan endapan pektin paling besar. Tetapi hasil dari kedua pelarut lebih kurang sama, yaitu hanya menghasilkan sangat sedikit endapan pektin. Sehingga untuk memisahkan endapan dengan pelarutnya, perlu dilakukan sentrifugasi selama 15 menit dengan kecepatan 8000 rpm. Dengan begitu, endapan dapat diambil dengan mudah dari pelarutnya. Kemudian pelarut yang tersisa diuapkan diatas penangas dengan menggunakan cawan pada suhu rendah $(60 \square C)$. Selanjutnya dikeringkan dengan oven pada suhu rendah (45-50 $\square$ C). Hasil rendemen pektin yang didapat dari metode ini hanya berkisar $0,003 \%$.

3. Isolasi pektin dengan metode perebusan

Pada tahap ini bagian yang digunakan adalah daging buah yang masih segar, tetapi untuk bagian kulitnya, digunakan dalam bentuk serbuk kering. Pada tahap ini dilakukan optimasi jumlah pelarut, suhu perebusan dan lama pengendapan. Perbandingan daging buah dengan aquadest didapatkan 1:3, sedangkan perbandingan serbuk kulit salak dengan aquadest didapatkan 1:6. Tahap perebusan dilakukan dengan pelarut aquadest dan dipanaskan pada 2 rentang suhu yaitu $80 \square C$ dan $95 \square$ C. Proses perebusan dilakukan dalam keadaan asam dengan $\mathrm{pH} 1,5$ dalam waktu selama 45 menit. Derajat keasaman pelarut mempengaruhi terhadap jumlah kandungan ion hydrogen, dimana berpengaruh karena dapat mensubstitusi kalsium dan magnesium dari molekul protopektin sehingga menyebabkan protopektin terhidrolisis menghasilkan pektin yang larut dalam air. Sedangkan pemanasan bertujuan untuk mempengaruhi ikatan antar molekul protopektin. Suhu yang tinggi menyebabkan ikatan antara molekul-molekul protopektin tersebut mudah terlepas dan larut dalam air. Hasil pemanasan disaring menggunakan kain saring hingga diperoleh filtrate. Filtrat dipekatkan menggunakan rotary evaporator hingga volume akhir yang didapat setengah dari volume awal. Pemekatan filtrate dilakukan 
agar penambahan etanol $96 \%$ tidak terlalu boros. Proses pengendapan dilakukan pada 2 waktu, yaitu diendapkan semalam (12-14 jam) dan selama 30 menit. Alkohol yang ditambahkan dalam larutan pektin akan bersifat sebagai pendehidroksi sehingga keseimbangan antara pektin dengan air akan terganggu dan pektin akan mengendap. Alkohol dapat merusak kesetimbangan air dan pektin karena alkohol berbobot molekul rendah sehingga akan bercampur sempurna dengan air melalui ikatan hidrogen. Penambahan alkohol ini akan mengurangi jumlah ion atau molekul air disekeliling pektin, sehingga pektin akan mengendap (Prasetyowati, dkk, 2009). Pektin dikeringkan pada suhu rendah $(40 \square-50 \square$ C) selama 8 jam. Dari metode ini didapatkan hasil rendeman yang jauh lebih banyak daripada menggunakan metode sokhletasi. Namun pada proses pengovenan harus selalu diamati suhunya sehingga pektin yang didapat tidak terlalu kering. Hasil rendemen pektin kering yang didapat, yaitu $1,225 \%$ untuk daging buah salak dan $6,708 \%$ untuk kulit buah salak.

4. Penetapan Baseline kelompok glukosa dan kelompok kolesterol

Setelah diaklimatisasi atau diadaptasikan selama seminggu, dilakukan penetapan baseline kadar glukosa dan kolesterol pada awal untuk mengetahui kadar normal tiap tikus, sehingga dapat dilakukan pengelompokkan dengan persebaran variasi kadar glukosa maupun kolesterol secara merata untuk menghindarkan kejadian bias. Darah diambil dari plexus retroorbitalis menggunakan pipa kapiler. Pada penetapan kadar glukosa digunakan sampel serum (tanpa penambahan antikoagulan) sedangkan pada penetapan kadar kolesterol digunakan sampel plasma (ditambahkan heparin). Untuk mendapatkan sampel serum maupun plasma, darah yang didapatkan disentrifuge selama 15 menit dengan kecepatan 3500 rpm. Serum dan plasma yang diperoleh langsung dianalisis kadar glukosa maupun kolesterol totalnya di LPPT. Serum maupun plasma harus segera dianalisis setelah didapatkan, untuk menghindari hasil yang bias. Hasil analisis kadar bisa diambil sehari setelah sampel dimasukkan. Kadar normal glukosa puasa untuk tikus disamakan dengan manusia, yaitu < $126 \mathrm{mg} / \mathrm{dl}$, didapatkan kadar normal untuk semua tikus.

5. Induksi hiperkolesterol dan hiperglikemia

Sebelum diberikan perlakuan, tikus harus diinduksi hiperglikemia untuk kelompok penurunan kadar 
glukosa dan hiperkolesterolemia untuk kelompok penurunan kadar kolesterol total. Pada tahap ini, tikus diberikan diet tinggi karbohidrat atau diet tinggi lemak sesuai dengan kelompok masingmasing. Berdasarkan literatur, induksi hiperkolesterolemia maupun hiperglikemia idealnya dapat tercapai antara 8 sampai 10 minggu. Tetapi induksi hanya dilakukan sampai minggu ke-3 pemberian diet dan belum didapatkan peningkatan kadar glukosa maupun kolesterol total secara signifikan. Untuk mempersingkat waktu, induksi diabetes dapat diberikan alloksan, sedangkan induksi hiperkolesterol dapat diinduksi poloxamer dengan pemberian secara intraperitoneal, akan tetapi dana yang diberikan tidak mencukupi, sehingga induksi hanya dilakukan dengan diet dan belum mencapai hasil yang diinginkan.

\section{Uji aktivitas secara in vivo}

Pada uji aktivitas, diberikan perlakuan selama 2 minggu untuk mengetahui apakah pektin yang diisolasi dari daging maupun kulit buah salak pondoh dapat memberikan pengaruh terhadap penurunan kadar kolesterol maupun glukosa darah. Akan tetapi, uji aktivitas ini belum bisa dilakukan sebelum induksi hiperkolesterol maupun hiperglikemik pada tercapai. Sehingga, uji aktivitas tidak dapat dilakukan karena keterbatasan waktu dan dana.

\section{J. KESIMPULAN DAN SARAN \\ Kesimpulan}

Berdasarkan penelitian terhadap "Pemanfaatan Pektin yang Diisolasi dari Kulit dan Buah Salak (Salacca Edulis Reinw) dalam Uji In Vivo Penurunan Kadar Kolesterol dan Glukosa Darah pada Tikus Jantan Galur Wistar" yang telah dijalankan ini, maka dapat disimpulkan bahwa:

1. Kulit dan daging buah salak pondoh dapat dijadikan sebagai sumber pektin, dengan jumlah rendemen terbanyak terdapat pada bagian kulitnya, yaitu sebanyak $6,708 \%$.

2. Telah mendapatkan metode yang tepat dalam isolasi pektin dari kulit dan daging buah salak pondoh, yaitu metode perebusan, dengan memberikan hasil rendemen pektin kering yang jauh lebih banyak dibandingkan dengan metode sokhletasi, rata-ratanya $\pm 4 \%$.

3. Belum diketahui mengenai pektin yang diisolasi dari kulit dan daging buah salak pondoh memiliki aktifitas dalam menurunkan kadar kolesterol dan glukosa darah. 
4. Belum diketahui pengaruh pemberian pektin terhadap kadar kolesterol dan glukosa darah pada tikus jantan galur wistar, karena uji aktivitas secara in vivo tidak bisa dilanjutkan, disebabkan keterbatasan waktu maupun dana yang diberikan. Oleh karena itu, penelitian hanya sampai pada tahap induksi.

\section{Saran}

Warna coklat muda pada pektin dapat dicegah dengan penambahan $\mathrm{NaHSO}_{3}$ pada tahap pembuatan bubur asam daging maupun kulit buah salak pondoh. Serta kekurangan waktu dan dana dapat dicegah dengan estimasi dana yang diperlukan dan rencana B secara spesifik dan teliti untuk diajukan ke Dikti.

\section{K. DAFTAR PUSTAKA}

Anarsis, W., 1996, Agribisnis Komoditas Salak, Bumi Aksara, Jakarta.

Direktorat Gizi Departemen Kesehatan

Republik Indonesia, 1981, Daftar Komposisi Bahan Makanan, Bharata, Jakarta.

Lestari, R., Keil, S.H., dan Ebert, G., 2003, Variation In Fruit Quality of Different Salak Genotypes (Salacca zalacca (Gaert.) Voss) from Indonesia, Technological and Institutional Innovations for Sustainable Rural Development. Lestari, R., Ebert, G., dana Keil, S.H., 2013, Fruit Quqlity Changes of Salak "Pondoh" Fruits (Salacca zalacca (Gaert.) Voss) during Maturation and Ripening, Journal of Food Research, 2(1): 204-216. Marks, D.B., Allan D. Marks, dan Smith C.M., 1996, Biokimia Kedokteran Dasar: Sebuah Pendekatan Klinis, EGC, Jakarta.

Mattes, F., 2005, Cholesterol and the Power of Pectin, Herbstreith and Fox Inc., Elmsford/New York, USA.

Mawarti, H., dan Ratnawati, R., 2012, Penghambatan Peningkatan Kadar Kolesterol Pada Diet Tinggi Lemak Oleh Epigallocatechin Gallate (EGCG) Teh Hijau Klon Gmb4, Jurnal Keperawatan Unipdu, 1: 2.

Nazaruddin dan Kristiawati, 1992, 18 Varietas Salak, Penebar Swadaya, Jakarta.

Prasetyowati, Sari, K. P., dan Pesantri, H., 2009, Ekstraksi Pektin dari Kulit Mangga, Jurnal Teknik Kimia, 16: 4.

Sabari, 1983, Faktor-faktor Pengawet

Pada Buah Salak, Sub Balai Penelitian Tanaman Pangan

Pasar Minggu, Jakarta.

Sahputra, F.M., 2008, Potensi Ekstrak Kulit dan Daging Buah Salak Sebagai Antidiabetes, Skripsi, Fakultas Matematika dan IImu 
KHAZANAH, Vol. 7 No.2 Januari 2015

Pengetahuan Alam, Institut

Pertanian Bogor, Bogor.

Sharma, B.R., Naresh L., Dhuldoya

N.C., Merchant S.U., dan

Merchant U.C., 2006, An

Overview of Pectins, Times Food

Processing Journal, 44-51.

Srivastava, P., dan Rishabha M., 2011,

Sources of Pectin, Extraction,

Application in Pharmaceutical Industry, Indian Journal of

Natural Products and Resources, 2: 10-18.

Suter I.K., 1988, Telaah Sifat Buah

Salak di Bali Sebagai Dasar

Pembinaan Mutu Hasil, Tesis,

Fakultas Pasca Sarjana, Institut

Pertanian Bogor, Bogor.

Tsalissavrina, I., Wahono, D., dan Handayani, D., 2006, Pengaruh Pemberian Diet Tinggi Karbohidrat Dibandingkan Diet Tinggi Lemak Terhadap Kadar Trigliserida dan HDL Darah Pada Rattus novergicus Galur Wistar, Jurnal Kedokteran Brawijaya, 22: 2.

Winarno, F.G., 1986, Kimia Makanan,

PT. Gramedia Pustaka Utama, Jakarta.

Zubaidah, E., 2011, Pengaruh

Pemberian Cuka Apel dan Cuka

Salak terhadap Kadar Glukosa Darah Tikus Wistar yang Diberi Diet Tinggi Gula, Jurnal Teknologi Pertanian, 12(3): 163-169.

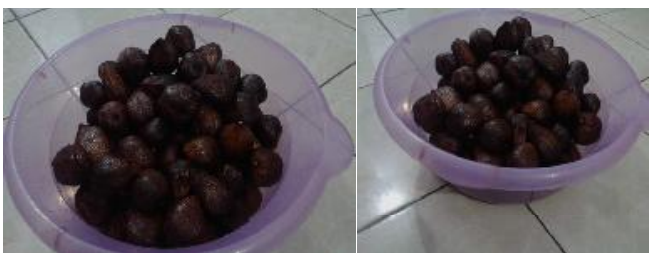

Gambar 1. Buah salak yang sudah dibersihkan dari kotoran yang menempel

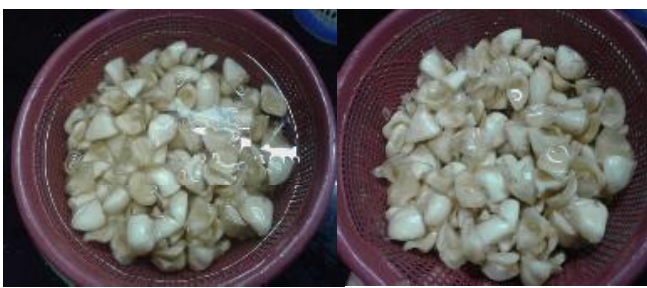

Gambar 2. Pencucian buah dengan air dingin untk mengurangi kadar gula pada buah
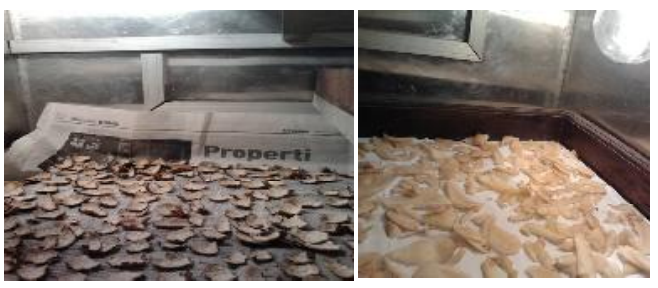

Gambar 3. Proses pengeringan kulit dan daging buah dalam lemari pengering



Gambar 4. Serbuk kulit dan daging buah salak 
Pemanfaatan Pektin Yang Diisolasi

.Pradhani, Crisdany, Zahra, Putri.

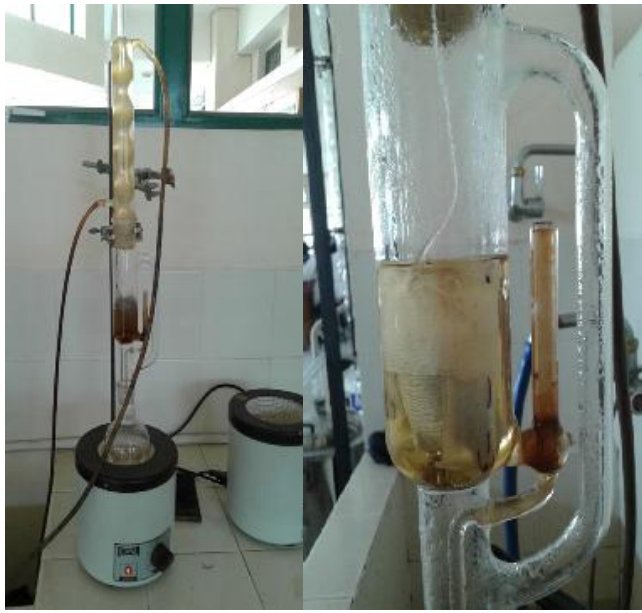

Gambar 5. Proses Soxhletasi serbuk kulit maupun daging buah salak pondoh

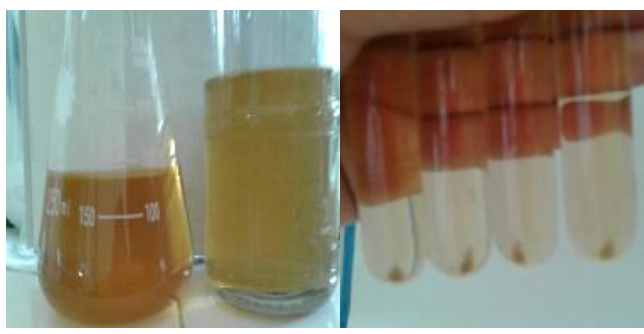

Gambar 6. Proses pengendapan pektin dengan dan tanpa penambahan asam (kanan ke kiri), serta hasil pektin setela proses sentrifugasi (atas dengan asam, bawah tanpa asam)

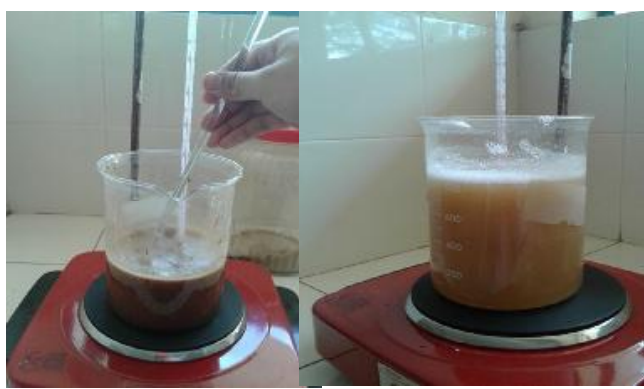

Gambar 7. Proses pemanasan pada metode perebusan

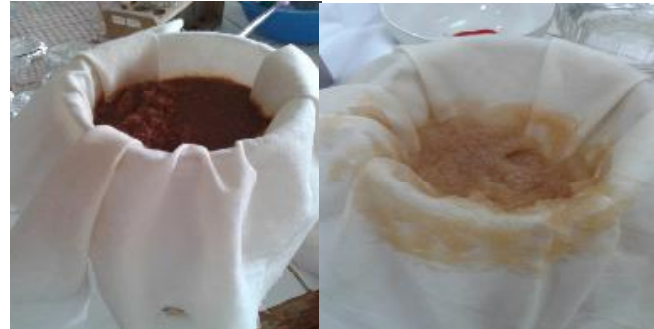

Gambar 8. Proses penyaringan

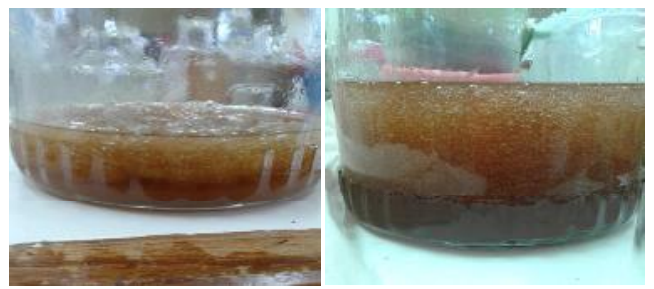

Gambar 9. Gumpalan pektin setelah penambahan etanol $96 \%$

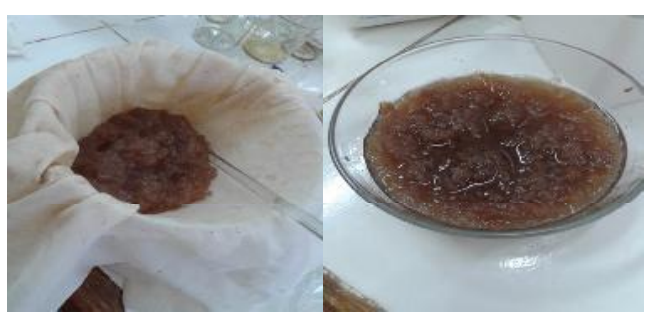

Gambar 10. Proses penyaringan dan pencucian pektin

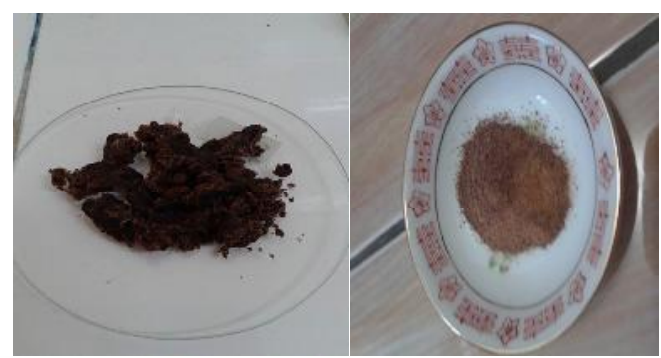

Gambar 11. Pektin kering sebelumdan setelah diserbuk 
KHAZANAH, Vol. 7 No.2 Januari 2015

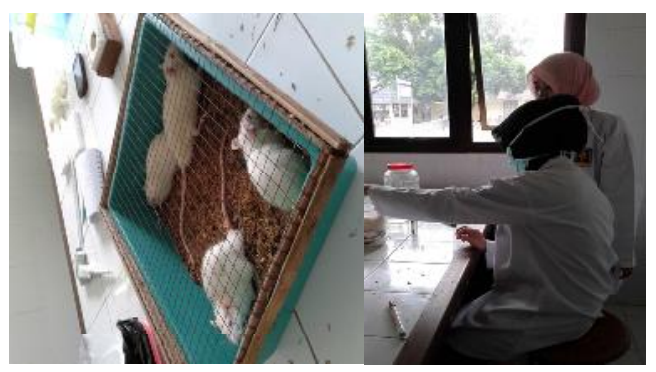

Gambar 12. Tikus jantan galur Wistar dilakukan anestesi inhalasi eter

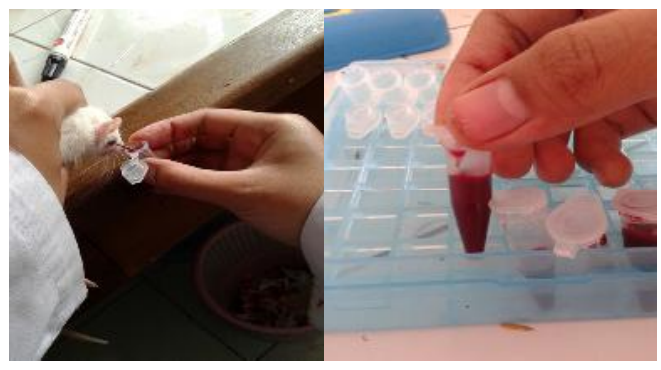

Gambar 13. Sampling darah dari plexus retroorbitalis
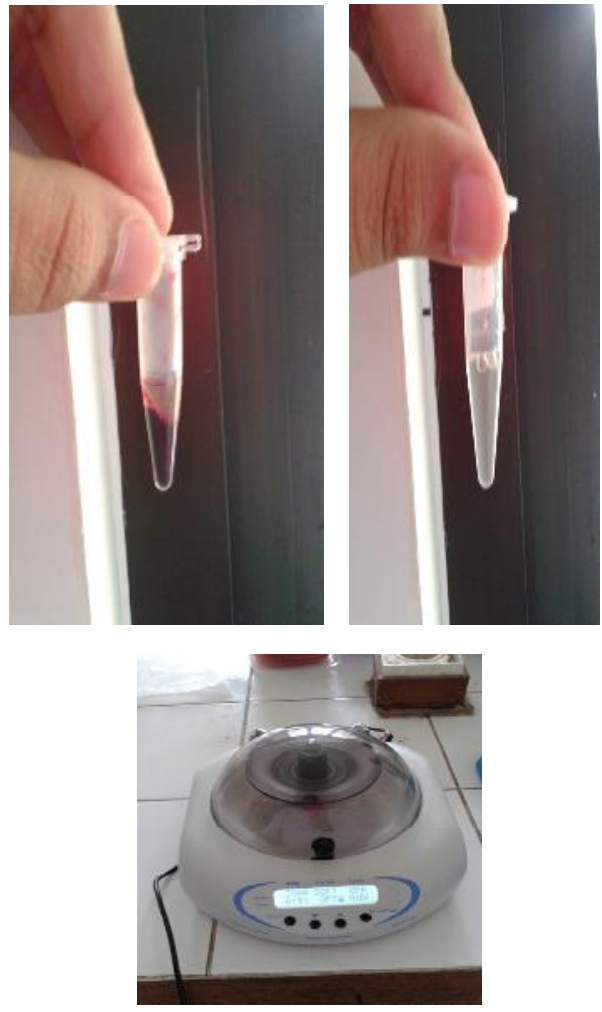

Gambar 14. Sentrifugasi untuk mendapatkan serum dan plasma 